REVISTA DE ESTUDOS EM ARTES CÊNICAS

E-ISSN 2358.6958

\title{
Processos criativos em Laboratório: A produção de intimidade no território disruptivo do tecnovívio
}

\author{
Martha de Mello Ribeiro
}

\section{Para citar este artigo:}

RIBEIRO, Marta de Mello. Processos criativos em Laboratório: A produção de intimidade no território disruptivo do tecnovívio. Urdimento - Revista de Estudos em Artes Cênicas, Florianópolis, v. 3, n. 42, dez. 2021.

do) DOI: http:/dx.doi.org/10.5965/1414573103422021e0118

Este artigo passou pelo Plagiarism Detection Software | iThenticate 


\title{
Processos criativos em Laboratório: \\ A produção de intimidade no território disruptivo do tecnovívio
}

Martha de Mello Ribeiro

\begin{abstract}
Resumo
Os processos biográficos/autoficcionais nos ensinam a enfrentar os dispositivos de controle biopolítico sobre nossa produção imaterial, especialmente os afetos. Essas narrativas de intimidade são um convite luminoso para a reinvenção radical do sujeito, para o refazimento do mapa de afetos e enfrentamento das "realidades" intimidantes. Essa promessa de intervenção e emancipação apontadas com as narrativas de intimidade ainda podem funcionar em um território virtual? A decolonização, desmercantilização e desprivatização dos corpos se realiza numa prática artística à distância? Onde não é possível o convívio entre corpos diversos? Como produzir corpos biopotentes no território disruptivo do tecnovívio? É o que esse ensaio busca refletir.
\end{abstract}

Palavras-chave: Autoficção. Biopotência. Decolonização.

\section{Creative processes in laboratory: the production of intimacy in the disruptive territory of virtual gatherings}

\begin{abstract}
Biographical/autofictional processes teach us to face the devices of biopolitical control over our immaterial production, especially the affections. These narratives of intimacy are a radiant invitation for the subject's radical reinvention, for the remake of the affection map and the confrontation of intimidating "realities". Can this promise of intervention and emancipation pointed out with narratives of intimacy still work in a virtual territory? Can the decolonization, demercantilization, and deprivatization of bodies be performed in a remote artistic practice? Where is the interaction between bodies impossible? How to produce bipotent bodies in the disruptive territory of virtual gatherings? This is the reflection proposed by this article.
\end{abstract}

Keywords: Autofiction. Biopotency. Decolonization.

${ }^{1}$ Pós-Doutorado em Teatro pela Universidade Estadual de Campinas (UNICAMP - FAPESP, 2010). Estágio de Pós-Doutorado na Università di Bologna (CAPES, 2015-2016). Doutora em Teoria e História Literária pela UNICAMP, com período sanduiche na Università di Torino (2007). Professora Associada no Departamento de Arte do Instituto de Arte e Comunicação Social da Universidade Federal Fluminense. Docente no Programa de Pós-Graduação em Estudos Contemporâneos. melloribeiro.uff@gmail.com

(6) http://lattes.cnpq.br/1477601900273409 (iD) https://orcid.org/0000-0001-9272-1013 


\title{
Procesos creativos en laboratorio: la producción de intimidad en el territorio disruptivo del tecnovivio
}

\begin{abstract}
Resumen
Los procesos biográficos/de autoficción nos enseñan a enfrentarnos a los dispositivos de control biopolítico sobre nuestra producción inmaterial, especialmente los afectos. Estas narrativas de intimidad son una luminosa invitación a la reinvención radical del sujeto, a la recomposición del mapa de los afectos y al afrontamiento de las intimidatorias "realidades". ¿ंPuede esta promesa de intervención y emancipación señalada con las narrativas de la intimidad seguir funcionando en un territorio virtual? ¿La decolonización, descommodificación y desprivatización de los cuerpos se lleva a cabo en una práctica artística a larga distancia? ¿Dónde no es posible la convivencia entre cuerpos diversos? ¿Cómo producir cuerpos biopotentes en el territorio disruptivo del tecnovivio? Eso es lo que este ensayo busca reflejar.
\end{abstract}

Palabras clave: Auto-ficción. Biopotencia. Decolonización. 
"Para que eu seja utopia, basta que eu seja um corpo" (Foucault, 2013, p.11)

"Se a perda da individualidade é de certa maneira imposta ao homem moderno, o artista the oferece uma revanche e a ocasião de encontrar-se" (Ligia Clark, 1965, p.05)

"Romper a linguagem para tocar na vida é fazer ou refazer o teatro" (Artaud, 1993, p.10)

Nas pioneiras experiências teatrais dos anos sessenta (citando como importantes nomes desta revolução, à qual podemos chamar como revolução do corpo, o Living Theatre, Jerzy Grotowski e Tadeusz Kantor), ocorre uma frenética redescoberta do corpo enquanto agente do acontecimento teatral, do entendimento da cena enquanto inventora de um espaço de entrelaçamento, um lugar do entre, que na justaposição de diferentes espaços e de uso de um tempo singular como num rito de festa (tempo não linear de ações simultâneas), cria um espaço outro: uma heterotopia, destinada a apagar todos os outros espaços; como assim pensado por Michel Foucault (2013, p.20). Os encenadores e mestres pedagogos do período compreendem o corpo como o lugar de partida e de chegada para a construção de uma nova teatralidade e principalmente para um novo pensamento sobre o teatro. Esses visionários homens do teatro, revolucionários artesãos da cena dos anos sessenta, protagonizaram uma profunda mudança sobre o pensamento da arte teatral: um percurso que ultrapassa uma busca preferencialmente estética para uma busca fundamentalmente ética, centrada principalmente no trabalho de preparação ou training do ator. Uma via para o autoconhecimento, da arte enquanto veículo para o auto-aprendizado. Esses reformadores da cena teatral têm em comum o fato de privilegiar em seus experimentos cênicos o encontro entre ator e espectador, ambos tomados como criadores da cena. É somente nos encontros que se produz o acontecimento, isto é, o teatro, ou melhor, um corpo-teatro.

Entendo o teatro como território privilegiado para o acontecimento e a criação de uma espacialidade heterotópica que instigue, em seu tensionamento com o real, novas possibilidades de construção criativas no mundo. Que possa 
enfrentar, no estar junto dos corpos (pois teatro é corpo com), os agenciamentos deste complexo sistema biopolítico e de representação contemporâneo. A palavra corpo-teatro é usada para dar nome ao corpo plural e difuso que se projeta no acontecimento teatral, instaurando, no território de sua singularidade, uma experiência entre corpos diversos. A pergunta que nos fazemos é: O que esse corpo, que é o teatro, tem a nos dizer ou ensinar sobre o isolamento social? Entendendo o corpo-teatro como um campo de forças que se expande nos encontros, uma cartografia de afetos que transforma a realidade visível, apontamos que é no encontro, justamente, que se constitui uma potência selvagem. Força capaz de derrubar instâncias de poder e de controle, pois ninguém é capaz de prever o que acontece num encontro. E é justamente essa imprevisibilidade que faz possível a realização de novos mundos, novas realidades. Uma nova realidade que se forma com a ruptura da tríplice regulagem do sistema representativo. O sistema de forças que controla o fazer, o dizer e o saber se desfaz assim na alegria de um mundo-festa: um território complexo onde se forma um comum feito de singularidades e contradições, onde se extrai uma verdade ética capaz de subverter a ordem vigente. Corpos juntos são extremamente subversivos, ocupações são subversivas, a escola é subversiva, o teatro é subversivo, as manifestações são extremamente subversivas. Há nessas aglomerações uma conjunção de corpos diversos que se juntam produzindo experiência, memória, invenção e afetos que se imprimem nos corpos, refazendo esses corpos.

A dimensão biológica da vida e sua permanência no plano das identidades não promove bons encontros, pois apequenam a vida, sabemos disso, a vida quer mais. Mas ainda assim nos espantamos quando lemos cartas de um doente terminal narrando as poesias que leu ou que escreveu, ou mesmo quando nos deparamos com o revolucionário que descreve seu passeio entre as flores de um vale bucólico, entre uma gargalhada e outra. Como se a dimensão biológica ou social da vida não permitisse com sua urgência certos desvios poéticos, inconsequentes e mesmo inúteis. A vida clama por uma partilha do sensível mais democrática, para falarmos junto à Rancière. Ser afetado é produzir um movimento de distração: olhar de forma difusa, desviar-se da realidade e devanear 
outros de si, na invenção de corpos heterotópicos. A distração nos faz percorrer pela superfície das coisas e criar novas invenções, no êxtase de ser absorvido pelo tempo da experiência de um encontro. A experiência não tem uma utilidade material, ela não serve para outra coisa além dela mesma. A experiência é o que nos acontece e o que nos acomete no acontecimento de um ato que dura no tempo. A experiência é totalmente inútil para a máquina de repetição do sistema de representação. Assim como a alegria, ela vale por si só, sua força está em sua capacidade de interromper esse sistema. Não é à toa que a alegria foi repelida pelas grandes narrativas do passado. Um herói não podia ser alegre, sua seriedade era valor instrumental para modelos identitários. Só os bobos da corte podiam se alegrar ou pessoas do povo, sem "nenhum" valor. Shakespeare foi o rei da distração! O rei dos bons encontros, escrevendo tragédias temperadas com fortes gargalhadas. E o que faz a gargalhada se não nos colocar diante de nós mesmos? Os exemplos são muitos, e pode ser que o leitor tenha esboçado um sorriso ao lembrar de alguma distração que o tenha carregado para alhures das urgências impostas pelo isolamento ou mesmo ter se distraído no exato momento da leitura desse texto, interrompendo-o para fabricar alegremente seu próprio texto. O que me daria muita alegria, mas peço licença para voltar ao ensaio.

"Quantos seres sou eu para buscar sempre do outro ser que me habita as realidades das contradições?’2, escreve Ligia Clark a Mário Pedrosa em 1967. Destaco essa interrogação da artista justamente por descrever de forma muito aguda a metodologia que venho buscando para pensar e problematizar no campo das artes/cena o corpo enquanto um campo de batalha de forças que o atravessam, na busca de uma ética dos afetos decolonizadora. As escritas e os diferentes usos dos corpos nas artes nos interessa na medida em que problematiza o corpo enquanto potência de transmutação e refazimento, pois todo corpo se faz com, daí seu poder de gênese. Esse com pode ser traduzido nas relações materiais e imateriais, não orgânicas ou orgânicas de afectibilidade do corpo, no poder do corpo em afetar e em ser afetado. Todo corpo produz linguagem e um campo de virtualidades, de ressonâncias, campo que Antonin 
Artaud nomeou como corpo sem órgãos, corpo que se faz duplo do corpo orgânico. Todo corpo é uma multiplicidade, todo corpo é uma singularidade, todo corpo é um dentro e um fora, todo corpo é também virtualidade ou um não-corpo que cria conexões subterrâneas, ainda invisíveis, com as forças externas que se dobram sobre ele. Certos experimentos artísticos, como por exemplo os Objetos Relacionais da brasileira Lígia Clark ${ }^{3}$ criam paisagens (ambiências) que formam fissuras no sistema de representação, colocando em relevo as forças de espessamento dos corpos. Criando densidade e opacidade no compartilhamento de vivências, esses experimentos modificam a posição do olhar ao inventar ou possibilitar novas relações, novas percepções e consequentemente diferentes afectibilidades, ampliando o que denomino como mapa de afetos do corpo. Essas experiências tão diferentes se aproximam, ao nosso ver, em seu desejo de convocar um tempo do olhar: um tempo que reivindica um esquecimento, uma distração ou mesmo um esvaziamento de nossas marcas perceptivas, ao mesmo tempo em que abrem passagens para outras conexões, mais "selvagens". Essas experiências convocam um olho não especialista e mais afetivo para a constituição de um corpo autopoiético. Limpar o olho para convocar esse tempo do olhar, na duração e intensidade das coisas ínfimas do mundo, é o que iremos pensar neste ensaio, convocando como ideia o corpo-teatro.

Nas proposições do Laboratório de Criação e Investigação da Cena Contemporânea (LCICC/UFF) busco diagnosticar os efeitos ou sintomas de uma cartografia social, cultural e política nas marcas de linguagem que se inscrevem sobre os corpos dos atores, no uso que fazem dos corpos e nas relações empreendidas com outros corpos. Busco entender cada corpo como uma teatralidade em curso, uma resposta mais ou menos criativa ou reativa ao sistema econômico-político-social e cultural, e também como um corpo capaz de se projetar no acontecimento de um corpo-teatro: um corpo que não é nem corpo blindado e nem corpo fantasma, e sim um corpo-poroso, permeável e com alta plasticidade e poder de gênese. Um corpo biopotente capaz de se reinventar, traçando um novo mapa de afetos, potencializando e afirmando a vida na

${ }^{3}$ Os Objetos Relacionais da (artista) propositora Lygia Clark é uma obra realizada entre 1976 a 1981, com algumas incursões até 1984. 
(re)invenção e no cuidado de si. A experimentação com os Objetos Relacionais de Ligia aponta um possível caminho para retomarmos, ainda que de forma sempre instável, a força vital do sujeito e da arte, amalgamados. É neste duplo experimento - arte(vida) - que vislumbramos um terreno fértil para novas redes de criação que possam tecer linhas de enfrentamento de um poder biopolítico. Fortalecendo cartografias de afetos, com palavras-afeto que resistam aos agenciamentos e às práticas coloniais, torna-se possível superar as marcas de rebaixamento impressas nos corpos, submetidos à realidades intimidantes. O teatro, com seu pensamento próprio, pode ser um dispositivo, uma condição metodológica para a decolonização dos nossos corpos. Quando digo pensamento próprio, quero dizer que o teatro pensa o mundo através da invenção, e na montagem/composição das imagens experimenta essa invenção no mundo, produzindo acontecimento. O teatro como acontecimento se faz na teatralidade (linguagem) e na performatividade (exposição) que friccionadas produzem uma experiência real (o acontecente). O teatro como um dispositivo para se experimentar relações na simultaneidade de tempos heterogêneos (passado-futuro-presente), colhendo o que de imprevisível e de inabitual pode ocorrer no acontecimento, para a abertura de um campo de forças do contraditório próprios ao convívio.

Conviver é uma arte, uma arte do encontro e, mais especificamente, uma arte do conflito. Entendo o conflito como um elemento fundamental para a construção de uma sociedade plural, justamente por evitar falsas relações consensuais que promoveriam o apagamento de modos diversos de existência, de produção imaterial, simulando uma romântica ideia de apaziguamento. A afirmativa de uma arte do conflito vai se desdobrar na pergunta: Como viver juntos, na complexidade de saber-nos sujeitos fraturados? Dilema que poderia se desdobrar em muitos outros pontos de interrogação, pois conviver é esse inefável dispositivo de produção de emoções, de afetos e de partilhas que nos levam a tantas outras perguntas que provavelmente não teriam respostas. Mas talvez, e essa é nossa aposta, o teatro possa provocar uma experiência excepcional para enfrentarmos a pergunta-dilema "Como viver juntos?”, em seus múltiplos tensionamentos éticopolíticos. E aqui cabe a pergunta, especialmente neste momento de isolamento social: O que o teatro teria para nos dizer ou ensinar sobre o convívio? Enquanto 
território privilegiado para uma convivência experimental e autopoética, o teatro nos ensina a sermos mais amorosos diante dos conflitos e mais interessados na escuta política e ética desse estar juntos, para além de uma esfera de poder e dominação. Queremos dizer também que pensar o conflito numa dimensão poética/corpo-afeto (e não apenas retórico-discursiva) é escapar da armadilha dogmática do saber, da autoridade do conceito, de um conhecimento discursivo dominante e superior que se imponha aos saberes do corpo e sobre outras epistemes. As emoções, afetos e sentimentos, assim como a arte, não se fundamentam numa lógica racionalizante, binária, fundamentada entre isso ou aquilo, trata-se de um saber que absorve simultaneamente isso e aquilo. 0 exercício crítico também se faz no diálogo conflituoso entre discursos e imaginários: são camadas de discursos sobrepostas, que respondem mais ou menos a uma imaginário coletivo, cultural, e que jamais irão captar uma palavra definitiva sobre a obra analisada. No melhor dos casos, o exercício crítico, em sua tagarelice, traindo muitas vezes a própria obra, faz a obra falar, mas essa fala é uma fala inventada, pois a crítica nada pode dizer sobre a verdade da obra.

Diante da importância do convívio para um fazer teatral emancipatório e decolonial, compartilho antes de continuarmos nossas análises, um incômodo: a percepção de uma certa euforia e de um entusiasmo rápido demais de alguns que enxergam no isolamento social a possibilidade de instalação de uma nova forma de expressão midiática, na qual a abolição do convívio traria como resultado positivo um maior alcance do teatro, ultrapassando geografias e seu eterno adversário, o tempo. O entusiasmo caminha numa linha que considero problemática, especialmente em sua dimensão ético-politica, ao afirmar uma espécie de vantagem nas plataformas virtuais, justificada pelo maior alcance dessas redes. Ainda que seja salutar abrir novos espaços para novas formas de comunicação e de expressão, nada contra a diversidade epistemológica, longe disso, devemos ser cautelosos. Não esqueçamos que se tratam de duas experiências muito distintas, já apontadas por Jorge Dubatti: a experiência do convívio e a experiência do tecnovívio (essa que estamos tendo aqui nesse momento de isolamento social pandêmico). Em minha análise, a irreflexão que estabelece comparações entre territórios tão diferentes esfumaça o poder 
disruptivo do isolamento social sobre o corpo-teatro, se deixando envolver pela sedução fria de se ver pulverizado em imagens, muito embora sejam imagens sem corpo, quiçá sem alma ${ }^{4}$. Gostaria então de fazer um convite para pensarmos juntos sobre o dispositivo teatro, na especificidade da experiência convivial.

Nesse momento de exceção no qual estamos vivendo, onde perdemos a possibilidade do convívio por causa do vírus que ameaça a vida, convidamos o leitor à pensar no poder de contágio do teatro. O teatro como peste, já nos disse Artaud, território da experiência convivial que em nada se assemelha à comunicação do tipo virótica, tecnológica que, como analisada por Baudrillard, se trata de uma comunicação direta que transmite, sem mediação, uma informação sobre o mundo. O poder de contágio do teatro não está em informar um mundo, mas inventar novos possíveis mundos. Convido à pensar o corpo-teatro como um corpo vivo, que convive com os organismos, que usa de suas estruturas para se fazer visível, mas que delas se mantém emancipado. Corpo que participa ativamente dessa pluralidade, dessa polifonia que é a cultura humana, mas sempre em permanente transmutação. Um corpo nada disciplinado, diria mesmo impertinente. Tantas vezes já se falou da morte do teatro, mas esse moribundo há mais de 2 mil anos muda seu traçado e emerge transfigurado, dando uma rasteira nas carpideiras, e se refaz vivo no luto do corpo que não the serve mais. O berço do teatro sempre foi o luto. Um corpo enlutado - um corpo en-lutado! Em luta. Um combate que se estabelece como força afirmativa da vida. Absorvendo todos os fantasmas, todos os sintomas, esse corpo-teatro dança às avessas no beiral de seu próprio túmulo. E não foi assim que nasceu o teatro? Na diferença de um corpo que carrega em si um coro em luto? Instaurando o conflito? O dissenso? Claro que neste momento tão desencantado em que vivemos, onde nos deparamos todos os dias com uma ameaça real de morte, se faz necessário valorizar a dimensão biológica da vida e nos isolar. A opção pela experiência do convívio não nos parece ser uma escolha possível atualmente. E o teatro, como arte do convívio, produtor de aglomerações, sofre um enorme impacto em sua economia, fundamentalmente convivial.

${ }^{4}$ Compreendendo o desgaste da palavra alma em nosso sistema de mundo, destaco que seu uso aqui não busca retomar uma anacrônica divisão entre corpo e alma, ao contrario. O sentido que buscamos é justamente pensar na impossibilidade de uma divisão entre alma/corpo/linguagem. 
Essa suspensão do convívio interrompe a obviedade do convívio. Tomando como exemplo a minha mão esquerda, ferida por um corte profundo no dia 08 de junho, confesso que até então, eu não pensava nessa mão. Ela não parecia fazer falta, por sua obviedade. Desdenhamos a obviedade. E agora que eu tive que interromper o uso dessa mão, eu vejo como ela me faz falta, a importância dessa mão para mim. Então eu quero usar essa metáfora, para pensar sobre essa privação da experiência do convívio, para pensar naquilo que o teatro fabrica de singular e o que esse território disruptivo tecnovival (convivência em modo remoto) traz de privação para a vida e o que traz de tensionamento para o corpo-teatro. Muito embora o teatro não tenha meios para propor grandes mudanças num plano macropolítico, sua espacialidade e economia pode revelar, no plano micropolítico, certas dimensões da vida invisibilizadas por esse nosso sistema de pensamento, construído por esferas de poder: vivemos num regime policial, com semblante de democracia, no qual ideias ou corpos divergentes são apagados em nome de uma segurança, do bom nome da paz, ou em prol de um status quo controlável, funcional para o regime. O que experimento no teatro convivial é um buscar-se, experimentar-se no outro que me transmuta e que me reinventa. Esse comumplural, que é o teatro, habita, neste momento, um território virtual. Questiono se no mundo das redes sociais seria possível inventar uma cena que não ceda às esferas maquínicas de poder; que possa promover um regime de sensibilidade e afetividade, ao reverso do sistema de representação. Como analisado pelo filósofo Jacques Rancière no livro $O$ destino das imagens, o regime de representação na arte "não é aquele em que a arte tem por tarefa produzir semelhanças. É o regime em que as semelhanças são submetidas à tríplice obrigação [do ver, do saber e do fazer]" (Rancière, 2012, p.130). As análises de Rancière adensam nosso debate na afirmação de que contrariamente ao regime de representação, no regime estético tudo é "igualmente representável”. Esse igualmente representável foi" a derrocada do sistema representativo", promovendo uma partilha mais democrática do sensível, vai dizer Rancière (2012, p.131). Essa partilha democrática se faz possível numa experiência remota? 
Nos exercícios presenciais do Laboratório $^{5}$ minha proposição inicial é o reaprendizado da respiração - ponto de partida para todo e qualquer movimento e a ponte para o corpo ativar e liberar as potências adormecidas ou atrofiadas pelas marcas de subjetivação coercitivas. O aprendizado da respiração é a via que leva o ator a eliminar os automatismos e se colocar em contato com seu corpo, com sua força vital. O corpo que respira fala em seu nome, ele se experimenta e se potencializa. A respiração é a consciência do corpo-ato. Quando o ator entra no modo de representação automático a respiração consciente o abandona e todo seu corpo deixa de se conectar com outros corpos. Então, o que vemos em cena são partes mortas ao lado de outras automatizadas: braços ausentes, olhar vago, pernas frouxas e mãos rápidas (automáticas). O corpo que não respira ou é um corpo reativo ou um corpo sem vontade própria. Os escritos de Antonin Artaud, contidos no O teatro e seu duplo, especialmente no texto Um atletismo afetivo, tratam fundamentalmente do corpo do ator e de sua relação com a respiração. Artaud vai dizer que o ator possui dois corpos, o corpo material (biológico) e o corpo virtual (imaterial). Ambos constituem o que denomino como mapa dos afetos. A respiração é a constante passagem entre os corpos, de modo a apresentar na cena um corpo vivo. Tudo que é vivo está em permanente atualização, e essa atualização no teatro se faz no acontecimento de um refazimento do corpo. O treinamento é a ferramenta para dar ao corpo seu protagonismo: o corpo me habita, neste dentro e fora de mim que sou eu. Meu corpo é um desconhecido familiar. Como dirá Foucault: está no corpo todas as nossas revoluções, invenções e utopias. As magias, os encantamentos, os super heróis, as fadas, os personagens de teatro são utopias do corpo, para a criação de um corpo incorporal que transcenda sua carne; talvez uma estratégia de fuga para aquilo que não dominamos e que nos escapa, nosso próprio corpo, esse real inatingível.

O pensamento de Artaud é fundamentalmente um pensamento politico do corpo. Pensamento que se constrói ao reverso do pensamento lógico

\footnotetext{
${ }^{5}$ Para maior detalhamento sobre os exercícios de respiração consultar Martha Ribeiro. 0 treinamento do ator no laboratório de criação e investigação da cena contemporânea. Pitágoras 500, 9(1), $132-$ 144. https://doi.org/10.20396/pita.v9i1.8655510. Disponível em:

https://periodicos.sbu.unicamp.br/ojs/index.php/pit500/article/view/8655510
} 
racionalizante. Sua ideia principal parte da ideia de um corpo sem órgãos com poder de gênese, capaz de criar uma nova anatomia. Um corpo capaz de acusar, com sua resplandecente vida, toda a ilusão do corpo-fantoche de deus: "[...] viver é voltar a si mesmo, a todo segundo, com obstinação, e é o esforço que o homem atual não quer mais fazer" (Artaud, Ouevres complètes, tomo XV, p.20). A necessidade de que fala Artaud - "voltar a si mesmo"- se conecta ao profundo significado do training para a arte do ator, na busca da libertação deste corpofantoche, corpo automatizado e escravo dos múltiplos agenciamentos que o dominam. Voltar a si, como afirma Artaud, está na ordem do rigor e da necessidade de uma experimentação cruel de si, que significa consciência e renúncia. Manter a conexão com o corpo, pela via da respiração, é o meio para se evitar os automatismos ou o caos generalizado, as convulsões sem sentido ou a abstração das formas. É na respiração consciente que o ator transmuta seu corpo, na conexão viva entre o corpo-matéria e o corpo-afeto, essa é toda a magia de que fala Artaud e posteriormente Foucault (2013, p.11):

Não há necessidade de mágica nem do feérico, não há necessidade de uma alma nem de uma morte para que eu seja ao mesmo tempo opaco e transparente, visível e invisível, vida e coisa: para que eu seja utopia, basta que eu seja um corpo. Todas aquelas utopias pelas quais eu esquivava meu corpo encontravam muito simplesmente seu modelo e seu ponto primeiro de aplicação, encontravam seu lugar de origem no meu próprio corpo.

A obra de Antonin Artaud é mesmo esse bisturi afiado que penetra no tecido da realidade, desviando e subvertendo sua lógica. Esse bisturi é feito da verdade ética do desejo e se faz na escuta do corpo e seus saberes. O trabalho de Antonin Artaud, em sua disposição para se conectar ao corpo, um corpo refeito em uma nova anatomia, traz para a arte do ator uma abertura fantástica. O ensaio Um atletismo afetivo, escrito pelo poeta ao final de 1935, descreve o ator como um "atleta do coração", aquele que em seu processo de trabalho "exercita" não os músculos, mas os afetos, isto é, a capacidade do corpo em afetar e em ser afetado. Palavras que instigam o ator a se lançar numa busca experimental, improvisacional, intuitiva e rigorosa de escuta do corpo, do que o corpo tem a nos dizer e a nos ensinar, fora da experiência do sujeito, de uma palavra soprada e 
introjetada. A obra viva de Artaud nos ajuda a pensar a arte da cena como território processual para reativar essa escuta do corpo, uma escuta que a cultura ocidental, com seus arranjos e dispositivos, tenta silenciar, concentrando e validando a experiência na centralidade do sujeito, no aspecto perceptivo, sensorial da vida concreta, escravizando o desejo em representações mortas. A ideia artaudiana de refazimento do corpo é, para nós, um possível território para se enfrentar os múltiplos agenciamentos do desejo, de nossa força vital. A via para esse enfrentamento é, sem duvida, a invenção. Buscamos lançar aqui a perspectiva de que o corpo é, potencialmente, um agente capaz de esculpir afetos, de construir uma rede de afecções outra que escape à "dobragem" das formas de poder em nossa força vital. Esculpir afetos seria, em nosso entendimento, uma ação eficaz e consciente (no sentido espinozista) impulsionada pela força vital contra à incorporação passiva de forças externas. Esculpir afetos, ou refazer o corpo, é uma ação criativa de combate aos processos maquínicos de subjetivação, reprodutores de subjetividades pré-concebidas, adequadas a uma determinada função, lugar ou comportamento. O corpo, como escultor de afetos, é um corpo que age! E aponta a linha de fuga dessa complexa adequação do desejo à formas pré-concebidas: um corpo com poder de gênese que se levanta contra à economia de um corpo dócil.

A subjetivação seria, conforme esclarece José Gil, uma incorporação de forças: "[...] entre um sistema institucional de poder e de saber e as forças do homem livre estabelece-se uma relação, de onde resultará uma captura das forças do indivíduo pelas forças do sistema" (Gil, 2003, p.23); o que se nomeia como biopoder, literalmente poder sobre a vida. Claro que nem tudo será absorvido pelo corpo, nem tudo the será permeável, mas algo se configura na fala de Gil e de Artaud, que somadas se apresentam como de grande importância para pensar as narrativas de intimidade como um dispositivo decolonizador. Algo interessante se estabelece entre essas ideias, que lança a inevitável pergunta: qual o poder do corpo diante dessas forças? E a pergunta inevitável surge, ou deveria surgir: Quais emoções eu sinto diante de um outro corpo? E por quais razões? Importante ressaltar, junto à Suely Rolnik (2018), que a resistência às afectibilidades do corpo se dá em um sujeito blindado, colonizado e triste, incapaz 
de escutar o alarme vital do corpo para agir afirmativamente diante da vida. A reatividade é contrária à pulsão. E aqui estamos diante de dois tipos de micropolítica do sujeito: a ativa e a reativa. A micropolítica do sujeito em processo afirma a vida, em sua vital potência de transmutação, onde o sujeito se coloca em obra, num trabalho de refazimento constante. Esse corpo vibrátil, biopotente supera os agenciamentos, os cálculos e a economia de uso dos corpos, justamente por sua permeabilidade aos afetos, aos acontecimentos.

Entender o corpo como um campo de contradições e com força de gênese se faz possível no ponto exato onde encontramos o teatro e no que existe entre nós, no que vibra eme entre nós. Trazendo como inspiração os Objetos Relacionais de Lygia Clark, observa-se que estes elementos são muito mais do que objetos, são estruturas-afetivas, com tal força de afectibilidade que causam rasgaduras nas realidades intimidantes, abrindo espaços para uma reinvenção ou melhor para um ensaio de nós, cuidadoso. Toda relação potente é também uma invenção de tempo, uma escuta-teatro, onde voltamos a nos aventurar. Os Objetos Relacionais nos levam à um ensaio entre nós. Quando Grotowski (1992) diz que a maior aventura é o ensaio ${ }^{6}$, se percebe que para o pedagogo teatral é justamente no ensaio que a magia pode acontecer, é ali que pode ocorrer o corpo-teatro, o acontecente. O ensaio é o que ainda não foi acordado, é o que ainda está em gênese, é um movimento entre o perder-se e o encontrar-se, experimentação que se põe em desacordo com o instituído. Este "não sei” próprio ao ensaio é o que pode dar passagem ao corpo-bicho de Ligia ou à verdade de um corpo sem órgãos que leva a uma transmutação do mapa de afetos, onde é possível superar o que não nos serve mais, o que não nos cabe mais. No ensaio toda escrita é reescrita, triturada, apagada, remodelada, devorada, cuspida, escarnada no acontecer do ensaio. Toda palavra-escrita, no ensaio, se volta contra um autor, transformandose em palavras-afeto que reivindicam sua emancipação como palavras-bicho. Para Suely Rolnik (1998), Lygia quer, com seus Objetos Relacionais, "resgatar a vida em sua potência criadora, seja qual for o terreno onde se exerça tal potência”, e completa, "Ele, homem, agora é o "bicho" e o diálogo é agora com ele mesmo, na 
medida da sua organicidade e também na medida da magia que ele pode emprestar de dentro dele mesmo"7.

E o que resta nesta operação entre corpos? Se nos é difícil dizer sobre o que há, sabemos dizer o que não é. O que resta não é uma estrutura “copiável”, da ordem do disciplinar, é algo que se instaura na ordem do precário, do não automatizado e não automatizável, é algo da dimensão do vivo. O que resta não é capturável, por se fazer na singularidade do acontecimento, na volatilidade e fluidez do agora. Rolnik (1998) identifica em Lygia o desejo de fazer de toda existência uma obra de arte, tal visada busco com os residentes do Laboratório: (1) no processo instável e volátil das narrativas biográficos/autoficcionais; (2) no campo das afecções contraditórias; (3) nos corpos não domesticados dos não atores. Ir ao encontro do outro, onde toda vida importa, é perguntar a cada um de nós: O que existe entre nós? Mas também, qual é sua língua própria? O problema singular que nos une? Aquilo que nos move e que nos afasta? Como se estabelece essa relação convivial no teatro? Busco por uma língua/linguagem polifônica, no movimento infinito de palavras-afeto que podem nos juntar em torno da busca por uma verdade ética, no combate à violência biopolítica contemporânea. Abrir passagem para o refazimento do mapa de afetos, novas dobraduras sobre os processo de subjetivação, ativadas na relação dos corpos com e entre os corpos. As narrativas de intimidade me aparecem disparadores para uma nova escritura, cuidado e invenção de si, um rascunho rizomático desenhado sobre as marcas de violência deixadas em nossos corpos.

As experiências biográficas/autoficcionais são um laboratório radical de subjetividades: corpos inquietos, em desassossego na invenção de novas linhas, cartografias e mapas de afeto. É na invenção de uma nova escritura sobre os cortes profundos e marcas da violência deixadas em nossos corpos que podemos decolonizar o pensamento e nos aventurar: "perder-se é um achar-se perigoso", nos diz Clarisse Linspector (1998, p.102). Habitar o inabitual e afirmar o poder da vida como arte, enfrentando as forças que tentam expropriar e extorquir a vida, e que introjetamos, é um convite para trabalharmo-nos. E a ferramenta aqui é o 
dispositivo teatro. As narrativas de intimidade permitem e propõem esse espaço de invenção radical de si, na dilatação e nas rasgaduras das últimas fronteiras entre o real e a ficção, conformando em tal espaço memórias, documentos, afetos e desejos como invenção e produção do corpo. Em minha hipótese, tal espaço se coloca como estratégico para o enfrentamento micropolítico dos complexos agenciamentos sofridos pelo corpo, na perversa manipulação do desejo, na tripla regulagem do ver, fazer e saber que replica um modelo hegemônico de orientação de mundo. Proporcionando novos lugares de fala e promovendo encontros afetivos "de verdade", no qual o ator lança mão, como estratégia de atuação, a confissão, na tecitura entre o mundo e sua intimidade, acentua-se o olhar para a geografia de corpos dissonantes num projeto ético-político-estético de um estar junto. Falei mais acima sobre uma "verdade ética" que emerge nesse "juntamento" de corpos. Aqui destaco uma fala do Comitê Invisível: "A linguagem, longe de servir para descrever o mundo, ajuda-nos sobretudo a construir um. As verdades éticas não são, assim, verdades sobre o Mundo, mas as verdades a partir das quais nós nele permanecemos" e continua: "São verdades que nos ligam, a nós mesmos, ao que nos rodeia e uns aos outros. Elas introduzem-nos de uma assentada numa vida comum, a uma existência não separada, sem consideração pelos muros ilusórios do nosso Eu” (Comitê Invisível, 2016, p.54).

Se Antígona enfrentou todo um país, se enfrentou seu soberano, o rei Creonte, para enterrar seu irmão de forma digna, fazendo uma insurreição contra uma lei estabelecida, foi porque ela estava ligada ao irmão, à cultura e às crenças do mundo em que habitava. Guiada por essa verdade ética, Antígona enfrenta a própria morte, revelando com seu gesto político essa existência não separada, a pulsão vital de um corpo coletivo. Antígona, com seu gesto, faz muito mais do que representar à ela mesma, não se trata de uma disputa familiar, particular e subjetiva apenas. O gesto de Antígona é o levante de todo um corpo coletivo que questiona a lei, a lógica de Creonte: uma lei que impõe uma vida que não merece ser vivida. O gesto de Antígona é a revelação desse comum, da soberania de uma verdade ética que se impõe contra toda estrutura de poder, contra uma ordem que cria desordem no mundo comum. A verdade ética nos ligam, nos amalgama em um corpo coletivo, somos muito mais do que esse temporário Eu que habita 
um corpo físico e biológico. A lei de Creonte se ergueu contra o mundo e contra uma verdade ética, e o mundo se voltou contra ele. Esse comum, potência de um corpo coletivo, é a força que pode mudar a realidade imposta pelas forças externas da lei. Essa talvez seja a maior contribuição do teatro ao mundo: descortinar as verdades éticas que nos unem enquanto sujeitos fraturados, derrubando os muros ilusórios que nos separam, produzindo intimidade entre nós. Mas esse ensaio busca também refletir sobre a possibilidade de construção de uma narrativa íntima no território disruptivo do tecnovívio ${ }^{8}$. Vamos empreender tal tarefa organizando um relato crítico sobre o vídeo“ Fala comigo!, uma autoficção de todo mundo", realizado com colaboradores em moto remoto durante o isolamento social (2020).

Nas etapas de criação do vídeo me questionei em todos os momentos se não estaria espetacularizando um privilegiado isolamento social, dando voz a um movimento de centralização narcísica do Eu, produzindo imagens destituídas de mundo, de alteridade e, ainda pior, imagens apaziguadas de uma classe média minoritária e favorecida. Minhas dúvidas me fizeram buscar, com esse coletivo de classe média, em sua maioria branca e habitantes de territórios burgueses, imagens reveladoras desse alheamento subjetivo narcísico. A angustia sofrida com o isolamento, confessada nos encontros virtuais, me pareceu refletir uma importante e óbvia falta, a experiência convivial. Mas de que tipo de convívio fomos privados? Enquanto sujeitos fraturados que somos, sem uma verdade ética pela qual lutar e pela qual nos unir, muitos se abismam ainda mais em si mesmos, na busca de uma aparente melhor versão. O isolamento físico, forçado, me parece acentuar um isolamento ainda maior, que responde a esse sentimento de não pertencimento ao mundo, o que faz tudo à volta parecer ainda amais irreal, ou mesmo um deserto. A reação imediata e irrefletida é o mergulho em uma profusão

\footnotetext{
${ }^{8}$ O termo tecnovívio é usado por Jorge Dubatti como dispositivo para pensar o teatro enquanto uma arte do convívio. São duas experiências muito distintas, já apontadas pelo autor: a experiência do convívio e a experiência do tecnovívio. Ver: Dubatti, 2016.

9 Primeira produção do Laboratório de Criação e Investigação da Cena Contemporânea em modo remoto, o vídeo conta com a colaboração de artistas de diversas partes do Brasil. Criação, Pesquisa, Direção, Roteiro e Montagem do vídeo de Martha Ribeiro. Edição técnica de vídeo: Thales Ferreira. Som: Gerbert Périssé. Com a participação de: Biah Triles, Bruna Testi, Elisa Barbato, Gerbert Périssé, Jak Tacura, Lucas Brunno, Luísa Zanni, Maria Luisa Sá, Martha Ribeiro, Raiana Vinhal, Raíza Rameh, Rebeca Tolmasquim, Sara Vinhal, Thales Ferreira, Tito, Zé Caetano. Disponível no canal Youtube do LCICC (lcicc_uff). https://www.youtube.com/playlist?list=PLewP4P3XBOAplJK2PjrFj7fAKqJgiv67v
} 
de imagens selecionadas, manipuladas e artificiais do corpo, da casa, da voz, imagens fraturadas em milhões de espelhos, alimentando um artificioso sentimento de criação de mundo e de identidade. Mas qual mundo pensamos estar criando nestes dispositivos remotos? E por qual mundo se está lamentando? O titulo que dei ao experimento - "Fala comigo!" - responde à uma suplica, um grito de quem escavou um deserto sobre seus próprios pés, e muito antes da pandemia.

Observo neste momento de exceção, de isolamento social imposto, uma repetição nos discursos de quase todos os participantes desse experimento virtual: a falta melancólica das familiares estratégias ilusórias que simulam a construção de um "coletivo", de classe média, cimentado por muitos (não) encontros quaisquer. Viver junto não é uma coisa fácil, mas também não gostaríamos de viver sozinhos, isolados, pelo menos não a maioria de nós. E o filosofo Schopenhauer já pensou muito antes desta pandemia que talvez sejamos uma forma de porco-espinho. Sabemos que a solidão e o frio nos castiga, o que nos leva invariavelmente a buscar o contato com outro corpo, para assim nos aquecermos mutuamente. Estreitando nossa aproximação com o outro, acreditamos idealmente que tal convívio íntimo nos aqueceria o corpo e a alma e que finalmente viver juntos nos libertaria do frio e da solidão. Mas infelizmente não é assim que acontece. Essa mesma proximidade ao invés de nos alegrar permanentemente, passa a nos incomodar e até pode nos causar danos, pelos espinhos, nossos e do outro. Assim, nos afastamos e nos isolamos novamente, até que chegue outra vez o frio ou a solidão e tentamos de novo voltar ao convívio, repetindo o mesmo resultado.

Como habitar um mundo real, se ainda gostaríamos de acreditar que o melhor dos mundos é aquele onde não se estabelece conflitos? Como sair do espetáculo narcísico se permanecemos fechados em nosso repertório, entre ilusões e semelhanças sem devir? Para criar e trabalhar passagens entre nós, fabricando rasgaduras nessa realidade ilusória e deserta de real, é necessário uma boa dose de coragem para se arriscar para fora da caverna. Sair do invólucro social, econômico e politico ilusório, alienante e arriscar-se numa experiência do fora de si é o que me parecia o mais complexo a se conseguir nessa experiência remota. 
E reverberando Suely Rolnik (2018, p.25): “o regime colonial-capitalístico exerce essa sua sedução perversa sobre o desejo cada vez mais violenta e refinadamente, levando-o a se entregar ainda mais gozosamente ao abuso". E o abuso é o poder dos agenciamentos sobre nossos afetos e desejos, impedindo a criação de novas formas de realidade, impedindo o olhar cruel sobre nós, dessa necessária e rigorosa crueldade política e poética sobre nós mesmos, que Artaud convocou em palavras supliciadas. O vídeo ganha então um propósito: ser um convite à crueldade, na aceitação de nossa infinita ignorância sobre nós, sobre o outro e sobre essa ilusão de mundo, à partir da montagem de imagens complacentes que refletem uma micropolítica colonial dos corpos e do pensamento, projetada em versões líquidas de nós

"Fala comigo! uma autoficção de todo mundo"10 é um experimento em vídeo que se desenvolveu desconstruindo modelos de vídeo-criação que se fazem com roteiros pré-determinados. À partir de ações diversas que direcionei à cada grupo (4 no total) ou a cada um dos indivíduos participantes, solicitei aos colaboradores que as executassem em seu espaço de isolamento e que as registrassem em vídeo, usando a câmera de seus celulares ou que gravassem os encontros coletivos, organizados na plataforma Google Meet ou no Instagram. Montei cada vídeo (5 tesears e 1 vídeo completo) usando as cenas auto-filmadas de forma livre, muitas vezes descontextualizando o que foi pedido ou apresentado, realizando novas combinações e fusões, intervindo de forma violenta sobre as imagens. Amalgamei as ações de forma a construir um roteiro posterior ao arquivo das imagens captadas, buscando empregar uma voz narrativa (minha própria voz) que tecesse essas "atrações" mantendo a fragmentação das imagens, inventando com a narrativa uma história de amor interrompida. A narrativa de um suposto desencontro amoroso se colava assim a uma conjunção de imagens e arquivos fragmentados sem estabelecer um vínculo descritivo entre palavra e imagem, em ressonância ao triste jogo da vida que se faz nas redes sociais.

10 Primeira produção do Laboratório criada e produzida em modo remoto, contando com artistas de diversas partes do Brasil. 
Como exemplo dos exercícios/ações propostas, citamos: "Movimentos aleatórios para contatos autoficcionais"11; "Contato com a lua"; "Sons corporais e cotidianos"; “Janelas e portas”; "Pergaminho do ovo”; “Lives”; “Encontros e cuidados de si"; "histórias inventadas"; etc. Cada exercício desse provocava um turbilhão de imagens e sons enviados pelos colaboradores, cada qual oferecendo um ponto de vista singular e diverso sobre os exercícios e ações pedidas, aumentando ainda mais a complexidade da montagem. Optei por realizar pequenos vídeos (teasers), um de cada grupo, como forma de melhor organizar o plano final de montagem. Em “Fala comigo!", o processo se organizou em três módulos de criação/ação afetivas e cognitivas, no espaço interior da casa de cada um dos colaboradores. Ações que, todas elas, apontavam para um desejo de reconexão com o outro, com o mundo e com a natureza e, principalmente, uma busca por si, entre tantas imagens e versões virtuais. Montei, pedaço por pedaço, selecionando pequenos intervalos (anotados num papel, antes de passar para o operador de edição) diversos fragmentos das cenas fílmicas que os colaboradores foram produzindo, instigados pelos exercícios que propus ao longo dos encontros. Os módulos de criação assim se dividiram: 1. casa organismo/imagens, sons e cores; 2. Afetos de isolamento e Narrativas ficcionais/romance, traição, reconhecimento, assassinato do narrador; 3. Montagem dos vídeos/introdução da voz narrativa.

Cada teaser que montei me deixei guiar pela percepção do mapa de afeto preponderante de cada grupo. Assim, cada um deles recebeu um subtítulo, correspondente ao agrupamento afetivo e narrativo que escolhi destacar, contaminada pelas imagens e conversas que tínhamos sobre o isolamento, nossas fragilidades, os diferentes atravessamentos das múltiplas e desencontradas emoções diante da ameaça do vírus e das incertezas sentidas e provadas, mas principalmente o enfrentamento da solidão. São eles: teaser 1 (lua); teaser 2 ( janelas); teaser 3 (desencontros); teaser 4 (mentiras). Cada subtítulo desse buscou entrever os afetos que se cruzavam nesse percurso autoficcional de todo mundo. No território disruptivo do tecnovívio, com nossos corpos fisicamente separados, buscamos, nestes 5 meses de processo, forjar alianças entre nós: fomos

${ }^{11}$ Esse exercício se encontra registrado em vídeo na plataforma Youtube. 
conhecidos, amigos íntimos, desconhecidos, rivais e amantes nessa rede de imagens simuladas de nós. O título do vídeo - "Fala comigo!" - nos diz sobre tantas vozes anônimas que numa garrafa de náufrago (a tela/janela) buscam encontrar outras vozes para se juntar e atravessar esse oceano de simulacros de um mundo em ilusão e convulsão.

O principal dispositivo que usei para pensar a montagem do vídeo experimental foi o conceito de "montagem das atrações" de Eisenstein, associado à exercícios ficcionais remotos e ações que propus aos colaboradores durante o processo, que durou aproximadamente cinco meses ${ }^{12}$. Na montagem dos vídeos parti de uma construção experimental baseada no conceito de" sinfonia de formas" de Eisenstein, quadros autônomos sobrepostos e simultâneos. Minha intenção foi, neste território do tecnovívio, de composição e de artifícios, contrapor o experimento de montagem à realidade do isolamento, simulando encontros afetivos virtuais e autoficcionais. A montagem funciona como uma zona/território que, na composição das imagens, se faz reveladora e transformadora de afetos, de emoções: uma composição na qual marulham desejos e sintomas, que provocam novas e diversas percepções e emoções em quem assiste. Se um dos sintomas mais significativos dos processos colonizadores e dos múltiplos agenciamentos que sofremos desde o nosso nascimento é a obediência à uma voz exterior que, aparentemente, detém um saber que não temos, como provocação, encarnei essa voz. Passei a solicitar aos colaboradores ações que tinham data e hora para serem realizadas, invadindo e interferindo na rotina diária de cada um deles mais enfaticamente. Claro que tudo foi sentido como um jogo, excitante e sedutor.

Mas se por um lado serviu como dispositivo para incrementar os exercícios, e provocar a execução das atividades, por outro lado revelou o quanto estamos disponíveis para continuarmos reféns, gozosamente servis ao desejo do outro e confortavelmente alienados de nós. E comecei a solicitar de forma mais firme as ações, inclusive com vídeos de mim mesma solicitando sua execução. A partir

12 Todo o processo de "Fala comigo! uma autoficção de todo mundo" se fez remotamente. Durante cinco meses (março à agosto de 2020). Na terceira etapa de criação, anterior à produção do vídeo final, montei 4 teasers, organizando os colaboradores em equipes, para uma maior produção de intimidade entre eles. Cada equipe se fez com um líder, pesquisadores do Laboratório. 
deste momento algo absolutamente interessante ocorreu: foi quando os colaboradores começaram a se juntar mais, a criar um organismo provisório entre eles. Mesmo sem nenhum deles dizer uma palavra, eu já sabia que eu era uma espécie de "divindade" (ou "inimiga") que eles precisavam responder coletivamente. Mas não estamos falando aqui da construção de uma verdade ética que se impõe contra uma lei artificialmente inventada como dispositivo de obediência e sim na revelação de um estado reativo do desejo, que ao se ver desafiado, dissociado de sua posição narcísica, se deixa guiar pela bússola do poder. Artifícios para a culpabilidade do outro e do gozo da autocomplacência, pelos quais se aceita o papel de reféns, e a profunda alienação de si. Solicitei então a morte dessa voz, minha morte, e foi surpreendente como essa se deu: um banquete antropofágico no qual eu era a carne a ser devorada. Os colaboradores com essa manobra me devolveram a alegria, dissipando um dos meus maiores temores ao dirigir e montar esse vídeo: me deixar seduzir pela voz autoritária e embrutecedora, ao revés de tudo que busco com o Laboratório e nos processos de treinamento dos atores.

Mas seria possível ter uma experiência autoficcional libertadora e reveladora de um "comum" (ou de uma verdade ética) neste território do tecnovívio?

Ter uma experiência coletiva entre lugares (atores, espectadores, técnicos) é o que separa o convívio do tecnovívio. Gosto de pensar o tecnovívio como uma espécie de impressão narcísica do ponto onde chegou (ou parou) nossa humanidade ou cultura, sem, no entanto, ser capaz de uma real experiência de criação. A criação sempre é da ordem de um tensionamento entre o singular e o coletivo ou entre o estranho e o familiar. O tecnovívio não nos ensina o convívio, essa difícil arte do conflito, reveladora de nossa vulnerabilidade diante das forças que nos atravessam e que, por isso mesmo, se constrói como um campo próprio para a transmutação. Nossa fragilidade diante das forças que se dobram sobre nós, traz desconforto, mas esse desconforto é o sinal que juntos estamos em movimento, e o movimento é criação de vida, é o que se opõe à conservação narcísica identitária. O tecnovívio é um registro identitário do ator, um documento informativo, um arquivo final e fechado de nós mesmos que podemos consultar a qualquer momento, sem nenhum enfrentamento com a fragilidade, o desconforto, 
a perplexidade ou mesmo a morte. Como não há morte também não há luto no tecnovívio, não há espanto, não há trabalho inventivo. No território do convívio, corpos se amalgamam numa zona conflituosa de forças, há a produção de um terceiro corpo, plural e inefável. Em nossa singularidade fazemos parte deste coro de enlutados e no luto afirmamos a potência da vida.

O modo identitário é um grande aliado dos organismos de poder e suas articulações biopoliticas, de controle regulador da sociedade. O sistema absorve como modelo a identidade de uma figura com algum poder de sedução para desviar o desejo legitimo de nossa força vital e simular desejos-função. Caricaturas para impor um tipo de funcionamento ao desejo, cafetinado pelos processos civilizatórios, disciplinares e de uma biopolítica que nos impõe uma individualidade determinada. Essa identidade produz uma pseudo subjetividade, especificamente criada para a sujeição obediente, que se impõe como modelo de uma desejada subjetividade perdida. Contra o modo identitário, de subjetividades autocomplacentes e vazias, Rolnik (1996, p.10) lança como arma de guerra o inconsciente maquínico-antropofágico: "força de resistência política à regra geral da homogeneização, engrenagem imprescindível do sistema em que vivemos". Todo organismo resiste à invenção. A diferenciação será sempre uma força, uma luta. A invenção é uma das dimensões da vida, diria que se trata da própria potência vital. Invenção e vida não estão em contradição, ao contrário. Assim como não é possível arrancar todos os ossos de nossa carne e continuarmos de pé, também não é possível arrancar a invenção da vida. A invenção são os ossos da vida: laço inexorável da vida com a invenção, aparência cheia de intensidades reais.

Com as ações "histórias inventadas", nas quais cada grupo tinha como meta inventar uma fábula, busquei ativar certos mecanismos comuns à construção do dramático, mecanismos de valores morais estabelecidos, para que de alguma forma ocorresse algum levante ético entre os colaboradores. Pedi a cada grupo que inventasse romances, traições, reconhecimentos e personagens entre eles, chegando ao assassinato do narrador, que sou eu. Com esse dispositivo pensei em "burlar" a ilusão narcísica de um eu soberano, produtor absoluto de imagens de si, totêmicas, dos atores e de mim mesma (em minha violência no uso das imagens). o experimento ficcional, sem que os colaboradores soubessem, buscava com a 
invenção de personagens morais, o levante de novas subjetividades e a desconstrução das certezas morais que tendem a conservar a realidade, a existência. Mas não creio ter atingido o objetivo em sua plenitude, qual seja, a criação autoficcional como potência para o refazimento do corpo e revelação de uma verdade ética, um comum que possa nos juntar. Foi fácil para os colaboradores caírem na armadilha das representações e de suas leis morais. Ainda que o Banquete antropofágico tenha mostrado um caminho possível, justamente por sua ousadia, ainda assim foi uma construção mental, articulada, artificial, incapaz de criar vida.

A pergunta que me fiz, precisa de pelo menos uma tentativa de resposta: "Mas é realmente possível ter uma experiência autoficcional libertadora e reveladora de um "comum" neste território do tecnovívio?" Não conseguimos encontrar uma resposta definitiva para a pergunta, apenas podemos falar dessa nossa primeira experiência. Sem nenhuma dúvida sinto um incômodo diante deste território disruptivo ao fazer teatral (que entendo como a arte do convívio) e aos processos de experimentação de si que conduzo no Laboratório, justamente por não ser possível a presença real do corpo. No território do tecnovívio, como esse das redes sociais e dos aplicativos (que utilizamos em todo o processo de experimentação), não há um conflito real, não há presença, não há alteridade ou uma singularidade outra que possa nos atravessar, só existem versões artificialmente "melhoradas". Consequentemente, não acontece uma real conscientização do ator de seu mapa de afetos e menos ainda processos decolonizadores. O lugar da fala se estabelece na hipertrofia de um Eu narcísico tagarela, que fala para si mesmo, produzindo imagens de si para si mesmo, ou seja, não se estabelece o diálogo conflituoso transformador, não se acessa a via para uma experiência do estranho-familiar. Com essa minha experiência no território do tecnovívio, afirmo o espelhamento narcísico, identitário, incapaz de atingir as camadas e dobras de nossos processos de subjetivação, ou seja, nosso mapa de afetos, impossibilitando qualquer criação de uma nova vida, transmutada com a potência da revelação de uma verdade ética. 


\section{Referências}

ARTAUD, Antonin. O teatro e seu duplo. São Paulo: Martins Fontes, 1993.

ARTAUD, Antonin. Ouevres complètes, tomo XV. Cahiers de Rodez. Paris: Gallimard, 1981.

BADIOU, Alain. Em busca do real perdido. Belo Horizonte: Autêntica Editora, 2017.

BARBA, Eugenio. A Canoa de Papel. Brasília: Ed. Dulcina, 2009.

CLARK, Lygia. A propósito da magia do objeto, 1965. Estamos domesticados?, 1964. In: Associação cultural Mundo de Lygia.

COMITÊ INVISÍVEL. Aos nossos amigos. Crise e Insurreição. São Paulo: n-1 edições, 2016.

CORNÁGO, Óscar. Atuar de "Verdade". A Confissão Como Estratégia Cênica. Urdimento - Revista de Estudo em Artes Cênicas, Florianópolis, v.2, n.13, p.099-111, 2018. Disponível em:

https://www.revistas.udesc.br/index.php/urdimento/article/view/141457310213200 9099. Acesso em: 20 abr. 2020.

CORNÁGO, Óscar. Biodrama: Sobre el teatro de la vida y la vida del teatro. Latin America Theatre Review. Kansas, v.39, n.01, p.05-28, 2005. Disponível em: https://journals.ku.edu/latr/article/view/1515. Acesso em: 10 jan. 2019.

DELEUZE, Gilles. Nietzsche e a filosofia. Rio de Janeiro: Semeion, 1976.

DELEUZE, PARNET. Diálogos. São Paulo: Editora Escuta, 1998.

DERRIDA, Jacques. A escritura e a diferença. São Paulo: Perspectiva, 1971.

DUBATTI, Jorge. O teatro dos mortos, introdução a uma filosofia do teatro. São Paulo: SESC, 2016.

FERAL, Josette. Teatro, teoria y páctica: más allá de las fronteras. Galerna: Buenos Aires, 2004.

FERNANDES, Sílvia. Teatralidades Contemporâneas. São Paulo: Perspectiva, 2010.

FOUCAULT, Michel. O corpo utópico, as heterotopias. São Paulo: N-1 edições, 2013.

GIL, José. Em busca da identidade, o desnorte. Lisboa: Relógio D’água, 2009.

GIL, José. O Corpo Paradoxal. In_ Movimento total. Lisboa: Relógio D’água: 2001. 
GROTOWSKI, Jerzy. O performer. Tradução de Celina Sodré. Conferência pronunciada por Grotowski e publicada pela Art-Press em 1987. Texto original em francês traduzido por Celina Sodré (sem publicação). Acesso em: 2013, compartilhamento de uma das alunas do Instituto do ator.

LINS, Sonia. Artes, 1996. Disponível em http://www.sonialins.com.br/ pdf/artes.pdf. Acesso em: 20 jan. 2021.

LISPECTOR, Clarice. A paixão segundo GH. Rio de Janeiro: Rocco, 1998.

LEHMANN, Hans-Thies. Teatro pós-dramático. São Paulo: Cosac \& Naify, 2007.

MARINIS, Marco. Capire il teatro, lineamenti di una nuova teatrologia. Firenze: Bulzoni, 1999.

PELBART, Peter Pál. Biopolítica. Sala Preta. São Paulo: USP, V. 7, s/n, p.57-66, 2007. Disponível em: https://www.revistas.usp.br/salapreta/article/view/57320.

Acesso em: 10 abr. 2020

RANCIÉRE, Jacques. O destino das imagens. Rio de Janeiro: Contraponto, 2012.

RIBEIRO, Martha. O treinamento do ator no laboratório de criação e investigação da cena contemporânea: a respiração como escultura de afetos. Revista Pitágoras 500, Campinas, v.9, n.1, p. 132-144, 2019. Disponível em: https://periodicos.sbu.unicamp.br/ojs/index.php/pit500/article/view/8655510.

Acesso em: 27 maio 2019.

RIBEIRO, Martha. Teatros do real e a abertura da representação. Urdimento Revista de Estudos em Artes Cênicas, Florianópolis, v. 1, n. 37, p. 344-355, 2020. Disponível em: https://www.revistas.udesc.br/index.php/urdimento/article/view/141457310137202 0344. Acesso em: 17 abr. 2020

ROLNIK, Suely. Esquizoanálise e Antropofagia. Texto apresentado no colóquio Encontros Internacionais Gilles Deleuze. Brasil, 1996. Disponível em: http://www4.pucsp.br/nucleodesubjetividade/Textos/SUELY/Antropesquizoan.pdf. Acesso em: 10 março, 2019.

ROLNIK, Suely. Esferas da insurreição. Notas para uma vida não cafetinada. São Paulo: n-1 edições, 2018.

ROLNIK, Suely. Por um estado de arte a atualidade de Lygia Clark. In: Núcleo Histórico: Antropofagia e Histórias de Canibalismos, São Paulo: Fundação Bienal de São Paulo, 1998.

ROLNIK, Suely. Lygia Clark, da obra ao acontecimento (Catálogo de exposição). São Paulo: Pinacoteca de São Paulo, 2006. 
ROLNIK, Suely. Lygia Clark e o hibrido arte/clínica. Disponível em: http://caosmose.net/suelyrolnik/

ROLNIK, Suely. O corpo vibrátil de Lygia Clark. In: Caderno Mais, Folha de São Paulo. São Paulo. Abril, 2000.

Recebido em: 07/06/2021

Aprovado em: 25/09/2021 